\title{
THE COOLEY SYNDROME IN AN ENGLISH CHILD
}

\author{
BY \\ E. G. L. BYWATERS, M.B., B.S., M.R.C.P. \\ (Late House Physician to the Miller General Hospital)
}

Cooley's erythroblastic anaemia has been reported in England before (Moncrieff and Whitby, 1934), but, with the two doubtful exceptions of a girl aged nineteen with a negative calcium balance, a marrow showing changes as in osteitis fibrosa and normal erythrocyte variability, mentioned by Vaughan (1936) and an infant with an English father ' of Southern European type' (Bush, 1937), only in children of Mediterranean stock. The only other two children of non-Mediterranean descent in the literature were one described respectively by Cooley (case IV) in his original paper (1927) (she and her father also had positive Wassermann reactions and she was subsequently omitted from the series) and by Grinnan, 1935 (case VIII), a boy of Anglo-Irish parentage, aged nine.

\section{Clinical Record}

Olive F., aged ten, is the fourth of five healthy children ranging from nine to eighteen years of age. Her father had influenza in Genoa during the War and again with appendicitis in 1934. He denies having had malaria or venereal disease and on routine examination appears healthy. His serum gave negative results for the Wassermann and Sigma reactions and his serum bilirubin was within normal limits. The only death among his four siblings and eight nieces and nephews was a sister who 'faded out' aged four months. The paternal grandfather was a healthy Sussex man and the grandmother claimed some German blood on her mother's side. The mother is one of a healthy family of eight, has had no miscarriages and is of English descent on both sides. She has never been abroad and has had no illnesses of note. Her serum showed a negative Wassermann reaction, normal fragility and normal bilirubin.

The patient has always been pale. In 1932 at the age of five she was jaundiced and had an enlarged spleen and liver, with a negative Wassermann reaction and hypochlorhydria. The blood showed then an anaemia of 40 per cent. Hb. (Dare) ; R.B.C., 3.9 million per c. mm.; normal white count ; bilirubin, 1-4 units ; fragility, 0.4-0.3 per cent. ; reticulocytes, 5-7 per cent. ; and occasional nucleated red cells. No change in the blood picture occurred 
in spite of intensive liver, iron and stomach therapy (see fig. 1). In June, 1935, at the age of eight her spleen and appendix were removed and two transfusions given (Group II-A). The spleen was adherent to liver, stomach and colon. It was enlarged and weighed 200 grammes (normal at this age $=80$ grammes). Two spleniculi were also removed, one of which on section (figs. $2 a$ and $2 b$ ) showed marked proliferation of endothelial cells, some fibrous tissue hyperplasia especially of the capsule, large 'active' germ-centres to the Malpighian bodies, and little or no endarteritis, but some increased perivascular fibrous tissue. The pulp spaces were much reduced ; there were no islands of myeloid or erythropoietic tissue to be seen in the section except a small area at one

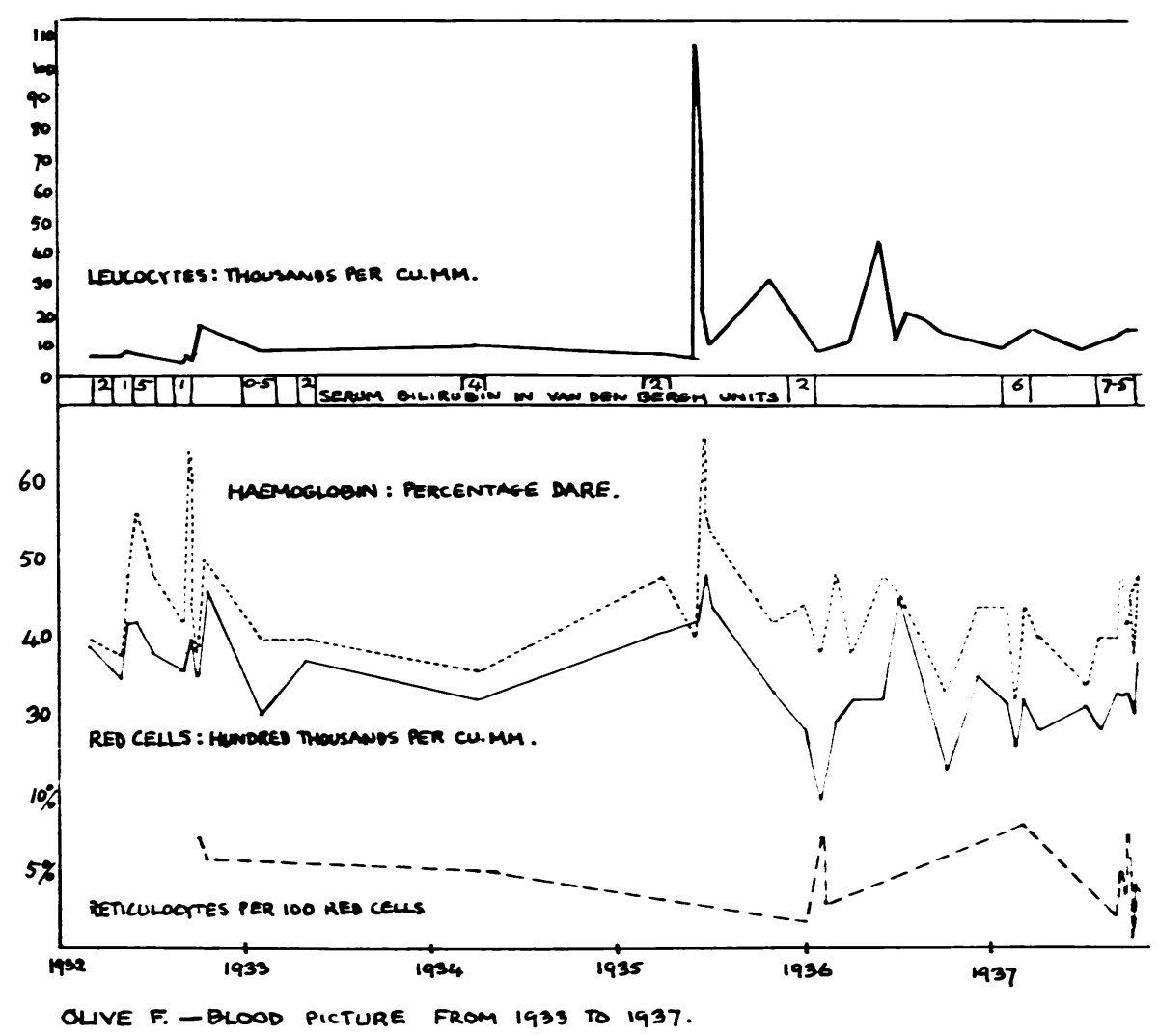

Fig. 1.-Chart of blood changes.

point under the capsule. No parasites were to be seen, no foam cells, no pigment, no sickling of the red corpuscles and few nucleated forms in the blood spaces.

These drastic measures temporarily raised her haemoglobin to 66 per cent. (Dare), but the red cell count remained stationary and the platelets normal. Splenectomy was followed by an empyema, which raised the white cells to 107,000 per c. $\mathrm{mm}$. The empyema was drained with rib-resection. Two months after splenectomy, the fragility of her corpuscles was recorded as $\mathbf{0 . 4}$ $0 \cdot 3$ per cent. (normal).

A year later her joints began to swell and an abscess in the chest wall was opened. Her blood showed a white count of 43,200 per c. mm., with 76 per 

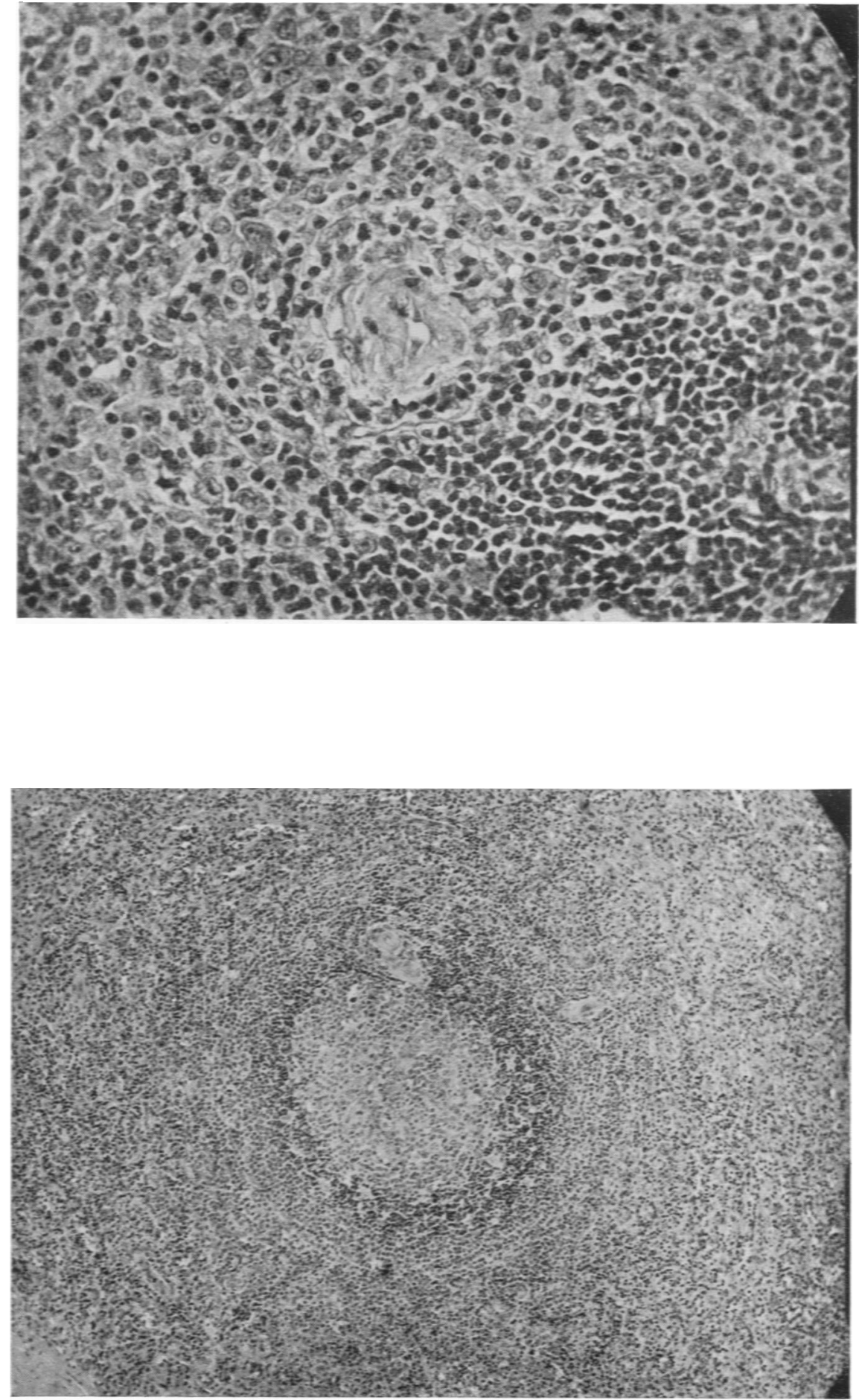
cent. polymorphonuclears, 2 per cent. myelocytes and numerous nucleated red cells. She has often shown a low-grade pyrexia.

Physical Examination: August 26, 1937.-The patient was a pale, intelligent girl weighing $53 \mathrm{lb} .6 \mathrm{oz}$. and of a muddy-yellow and freckled complexion. The photograph (fig. 3) shows a rather wide face across the cheek, which, although not mongoloid, is suggestive. No abnormality was found except the abdominal and thoracic scars, a liver about three fingers' breadths below the costal margin and a systolic murmur at the heart apex, which was

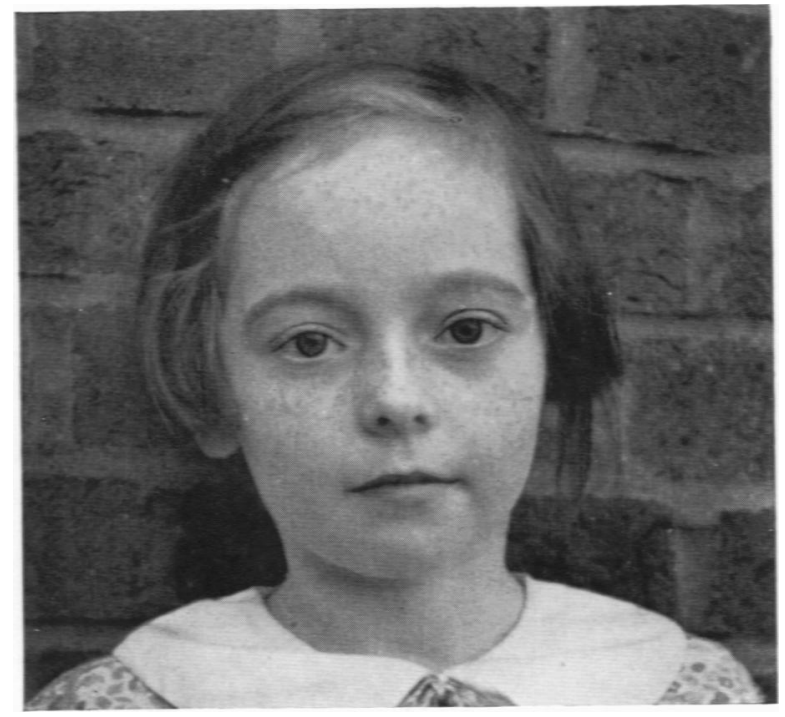

FIG. 3.-Photograph of patient, 1937.

displaced outwards. A teleradiogram of the heart (at 6 feet) showed a diameter of $11 \frac{1}{2} \mathrm{~cm}$., with enlargement of both ventricles. In particular the tongue and teeth were normal, as also was the chest. There was no evidence of joint disease or rickets and the lymph glands were not enlarged. An electrocardiogram shows slight left axis deviation.

The mean corpuscular volume by Wintrobe's method (1933), using his oxalated tube (Wintrobe and Landsberg, 1935), was $75 \mathrm{cu} . \mu$, mean corpuscular haemoglobin $23 \gamma \gamma$, mean corpuscular haemoglobin concentration 17 per cent. A Price-Jones curve (see fig. 4) from a film taken at the same time (July 24, 1937), measured by the method of Hynes and Martin (1936), showed a mean diameter of $8 \cdot 32 \mu$, a coefficient of variation 13 per cent., standard deviation $1 \cdot 08$, macrocytosis 40 per cent., microcytosis 2 per cent. The mean corpuscular thickness was thus $1 \cdot 39 \mu$, the diameter/thickness ratio $6: 1$, and the volume/ thickness ratio $54: 1$. Fresh blood showed no sickling in a sealed preparation from which air was excluded for two hours at $37^{\circ} \mathrm{C}$. There were many poikilocytes present and much crenation. Platelets numbered 192,000 per c. mm.

The stained film showed 14 per cent. of target forms in 1,000 red cells (Barratt, 1937). No parasites were seen either normally or by the thick film 
technique. Staining defects were seen in a variable proportion of the red cells-small, unstained areas, often oval or round, in the centre or periphery of the corpuscle, sometimes one, usually more than one in the cell. There was no obvious association with large or small, stippled, polychromatic or target forms. The defects were best seen by green light in films counterstained with eosin, when the centre of the defect often appeared to be filled up, producing $a$ 'ring' appearance (see figs. $5 a$ and $5 b$ ). The edges of the defects were

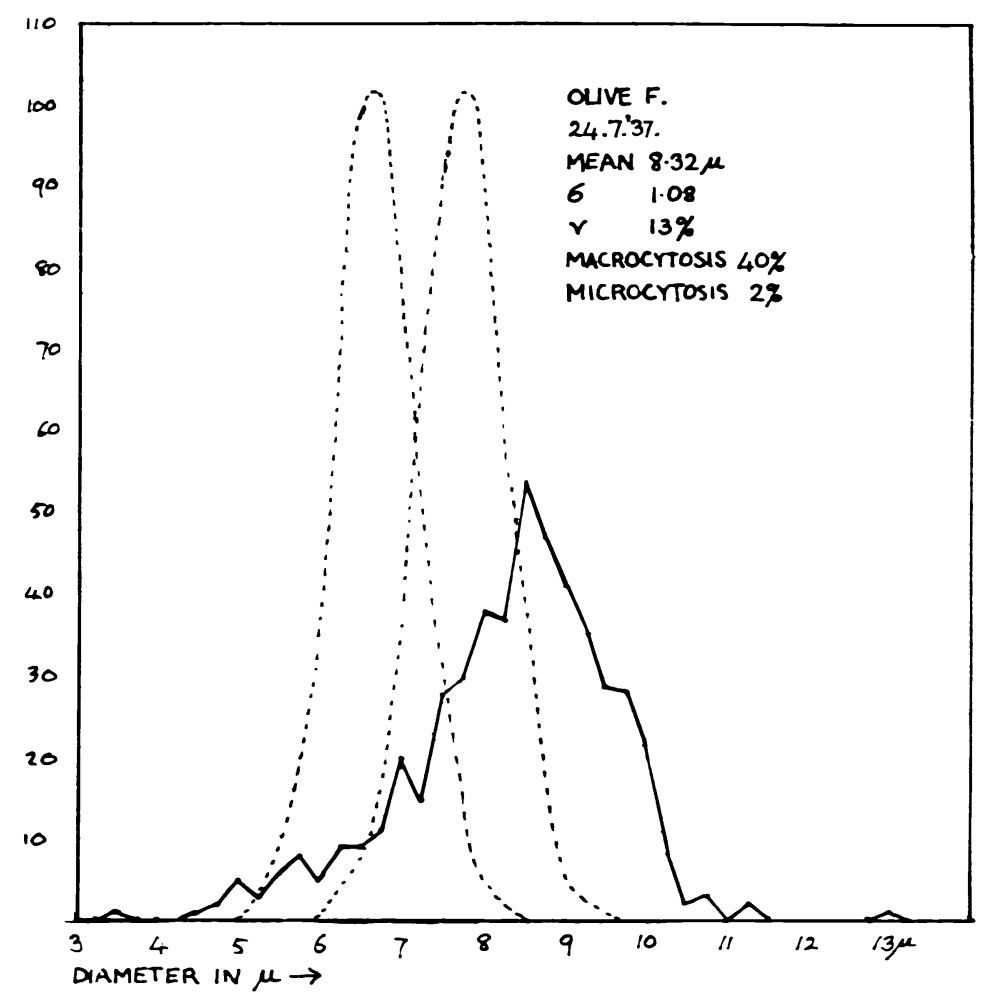

FIG. 4.-Price-Jones curve.

usually sharp, and, although no illustrations have yet appeared of these defects, they correspond with the description (" an uneven distribution of haemoglobin ') given first by Cooley and Lee in 1932. The resistance to hypotonic saline was increased and the span widened (fig. 6).

The Wassermann reaction was negative in 1932 and again in 1937, both before and six days after a fever-provoking dose of sulpharsphenamine. The Sigma reaction was also negative. The Mantoux test gave a negative result at a dilution of $1 / 1000$. 


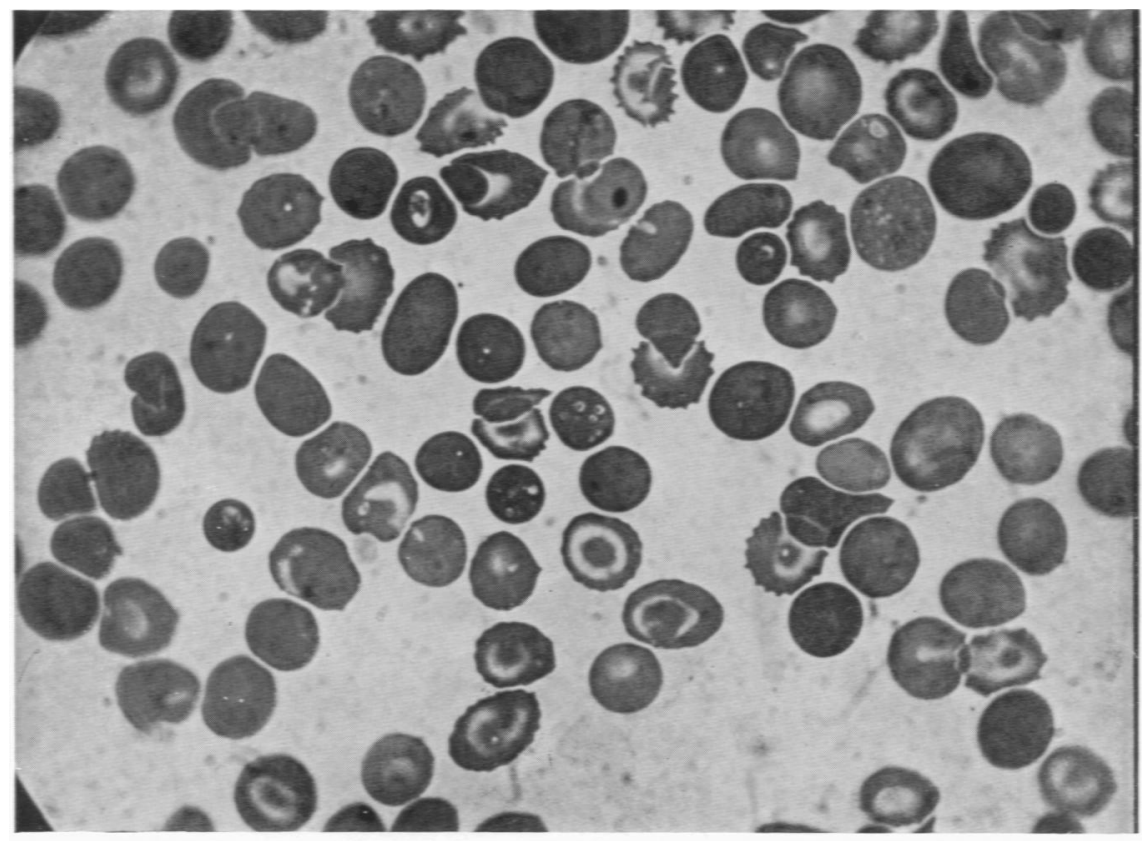

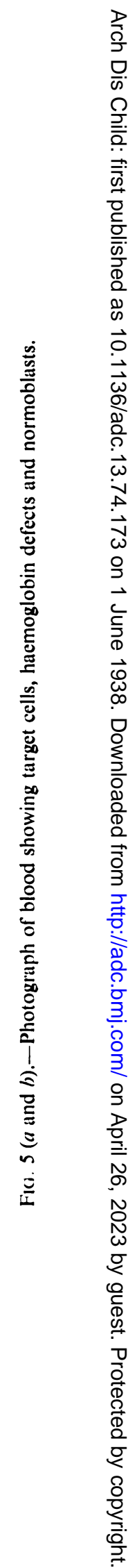




\begin{tabular}{|c|c|c|c|c|c|c|}
\hline \multicolumn{4}{|c|}{ BLOOD COUNT SHOWS: } & \multirow{2}{*}{$\begin{array}{c}24.7 .37 \\
3 \cdot 1 \\
8 \cdot 5 \\
5 \cdot 4\end{array}$} & \multirow{2}{*}{$\begin{array}{r}20.8 .37 \\
2 \cdot 8 \\
10 \cdot 4 \\
6 \cdot 4\end{array}$} & \multirow{2}{*}{$\begin{array}{r}1.9 .37 \\
3 \cdot 3 \\
17 \cdot 0 \\
6 \cdot 4\end{array}$} \\
\hline $\begin{array}{l}\text { R.B.C. mill. per c. mm. } \\
\text { W.B.C. thous. per c. mm } \\
\text { Hb. grammes per cent. }\end{array}$ & $\begin{array}{l}\cdots \\
\cdots \\
\cdots\end{array}$ & $\begin{array}{l}\cdots \\
\cdots \\
\cdots\end{array}$ & $\begin{array}{l}\cdots \\
\cdots \\
\cdots\end{array}$ & & & \\
\hline $\begin{array}{l}\text { Polymorphonuclears, per } \\
\text { Lymphocytes } \\
\text { Monocytes } \\
\text { Eosinophils } \\
\text { Mast cells } \\
\text { Myelocytes }\end{array}$ & $\begin{array}{l}\text { cent. } \\
., \\
., \\
\ddot{.}\end{array}$ & $\begin{array}{l}\cdots \\
\cdots \\
\cdots \\
\cdots \\
\cdots\end{array}$ & $\begin{array}{l}\cdots \\
\cdots \\
\cdots \\
\cdots \\
\cdots\end{array}$ & $\begin{array}{r}35 \\
55 \\
4 \\
2 \\
0 \\
4\end{array}$ & $\begin{array}{r}35 \\
50 \\
7 \\
7 \\
0 \\
1\end{array}$ & $\begin{array}{r}37 \\
56 \\
3 \\
4 \\
0 \\
0\end{array}$ \\
\hline $\begin{array}{l}\text { *Early erythroblasts (per } \\
\text { Late erythroblasts } \\
\text { Normoblasts }\end{array}$ & $\begin{array}{c}100 \mathrm{wh} \\
\quad "\end{array}$ & $\begin{array}{c}\text { ite cell } \\
,\end{array}$ & & $\begin{array}{r}1 \\
6 \\
600\end{array}$ & $\begin{array}{r}1 \\
6 \\
540\end{array}$ & $\begin{array}{r}1 \\
7 \\
640\end{array}$ \\
\hline Reticulocytes per 100 R.E & B.C. & . & $\ldots$ & $\begin{array}{c}\text { Not } \\
\text { enumerated }\end{array}$ & 3.0 & $2 \cdot 2$ \\
\hline Polychromasia & $\cdots$ & $\cdots$ & $\cdots$ & $\div+$ & - & $(\div)$ \\
\hline \multicolumn{3}{|c|}{ Cabot's rings and Howell-Jolly bodies } & . & $-\div+$ & $(-)$ & - \\
\hline Stippling & $\cdots$ & $\cdots$ & $\ldots$ & +-+ & - & $\div$ \\
\hline
\end{tabular}

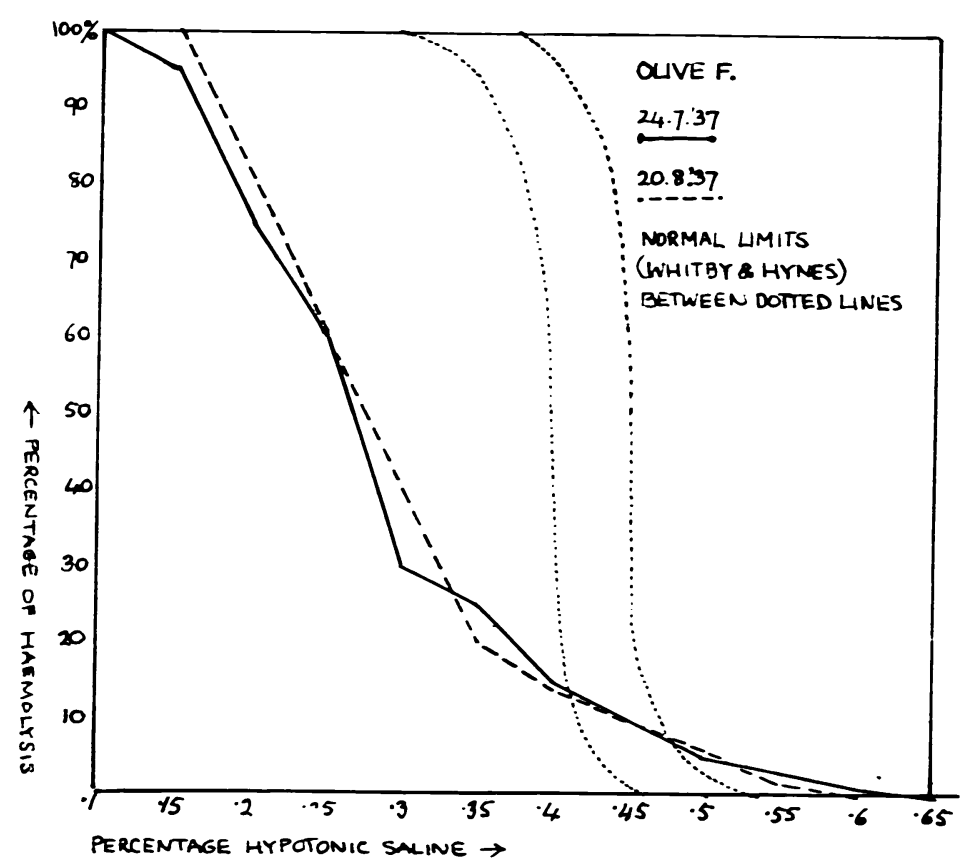

Fig. 6.-Fragility curve.

Biochemical Investigations.-The van den Bergh indirect method showed $2 \frac{1}{2}$ units of bilirubin ; the faecal fat was within normal limits; a fractional test meal showed free acid absent (September 1, 1937), and, a week later, free acid present in two out of seven specimens at two and two and a half hours.

\footnotetext{
* Nomenclature of Kato and Downey, 1933.
} 


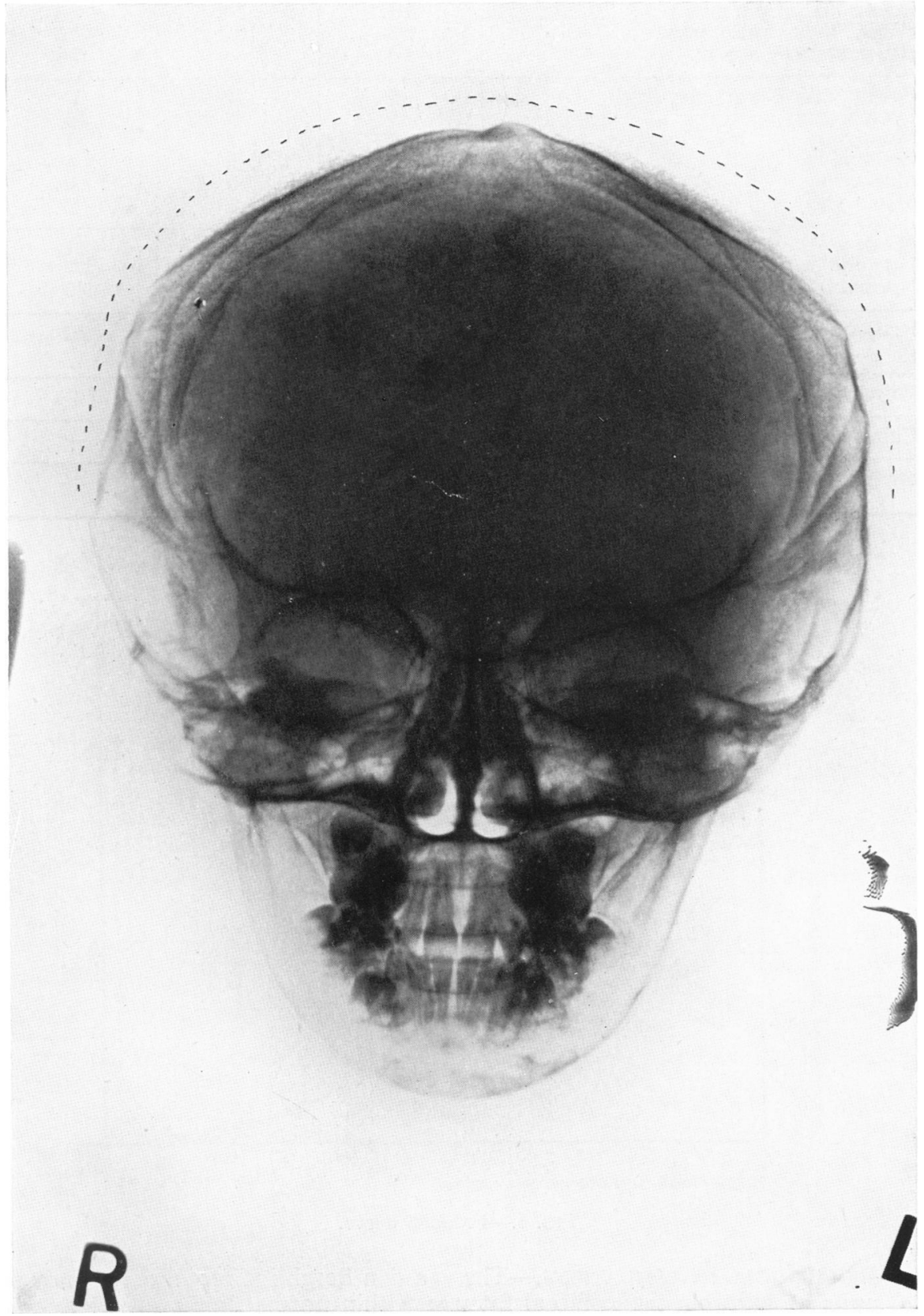

Fig. 7.-Skiagram of skull (antero-posterior), outlined outer surface. 
The urine showed a weakly positive reaction for urobilin and the faeces a strongly positive reaction.

Skeletal Changes.-The skull is enlarged. In the antero-posterior view (fig. 7), the parietal eminences are $1-1 \cdot 2 \mathrm{~cm}$. thick (teleradiogram). The outer table has almost disappeared, but the general density is increased. No spiculation is seen. In the lateral view, the characteristic thickening of the frontal

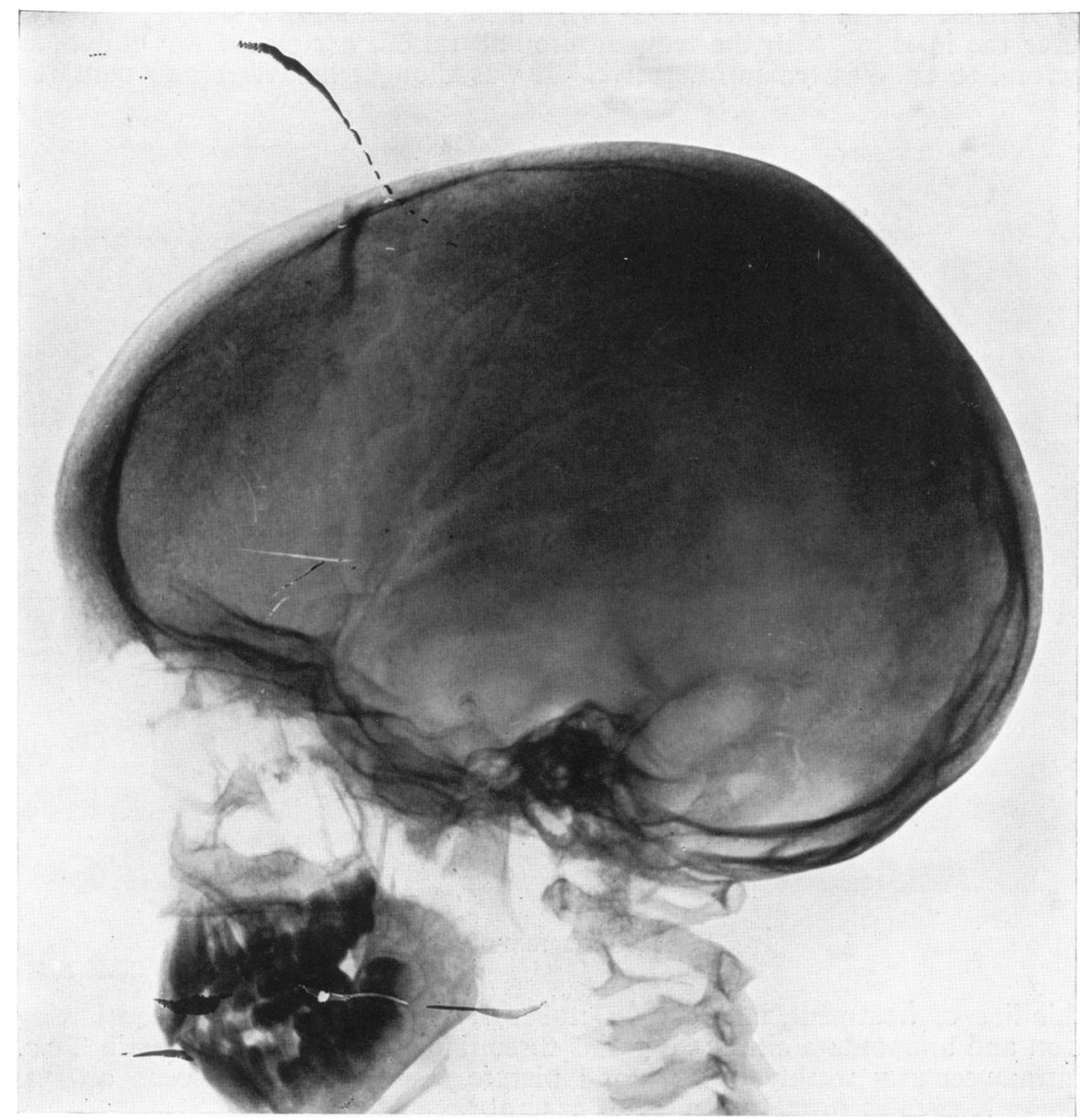

Fig. 8.-Skiagram of skull (lateral).

and occipital regions is seen (fig. 8). The clavicle shows rarefaction and a coarse trabeculation - changes that are seen also in the metacarpals and metatarsals. The characteristic increase in width is not seen except, slightly, in the fifth (fig. 9). The ribs show no evidence of rickets, but there is a fusiform thickening in the region of each tubercle (cf. Whipple and Bradford, 1936). The femur, tibia, radius and ulna show no abnormality except lines of bony arrest. 
TREATMENT.-The patient has been given liver extract, hog's stomach and iron for five years. For three weeks (beginning September 4, 1937) quinine and ethyl carbonate $7 \frac{1}{2}$ grains thrice daily were given after an initial test dose of 5 grains with no effect on haemoglobin, red cells or reticulocytes. Mercury ointment (60 grains) was then rubbed into the skin daily for a week from September 25,1937 , and potassium iodide given for two days until an iodide rash appeared. On September 29, 1937, sulpharsphenamine (0.015 gramme) was given intramuscularly with novocaine. This was followed two days later by malaise and fever (up to $102^{\circ} \mathrm{F}$.), which persisted for a week. Six days after the injection with the temperature still raised, her serum was found, as before, to be Wassermann negative. It was thought inadvisable to continue

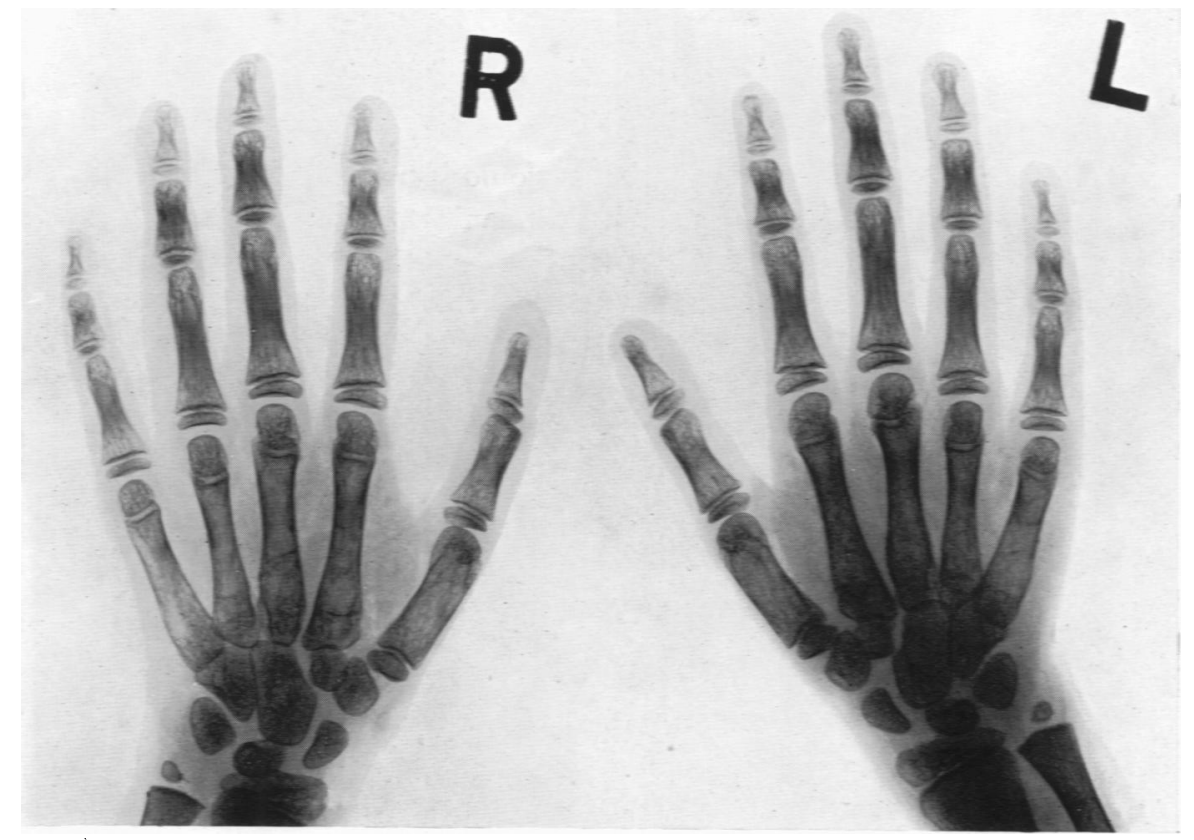

Fig. 9.-Skiagram of hands.

this line of treatment, and, since October 7, 1937, the child has been having iron and ammonium citrate 20 grains three times a day and anahaemin 2 c.c. intramuscularly weekly. Her blood picture is now as it has been always. Spray X-ray therapy (Hunter, 1936) has not been tried.

\section{Differential diagnosis}

The following must be considered :

A. Congenital syphilis.-The absence of other clinical evidence in the child and total absence in the parents, negative Wassermann reactions, especially after a provocative dose of sulpharsenobenzol and mercury, and the negative Wassermann reaction in mother and father would seem to exclude 
this. The staining defects in the red cells also were not seen in the original case IV of Cooley and Lee (1932) with congenital syphilis.

B. Congenital or neonatal malaria.-This is unlikely in England. Nittis and Spiliopoulos (1937) from Greece have recently reported success with antimalarial treatment in children who presented the Cooley syndrome, but which were indistinguishable, except for the absence of parasites, from congenital malaria. Spyropoulos (1936) also from Greece cites twelve infants and children showing secondary or symptomatic Von Jaksch' syndrome with liver and spleen enlargement, normoblastosis, anaemia and leucocytosis, some with mongoloid features (no skiagrams) due to such diseases as malaria (two cases), leishmaniasis (three cases), chronic tonsillar infection, toxic-infectious hepatitis, 'alimentary' anaemia, and 'geophagic ' anaemia with nematodes; all cured by specific methods. In the child described here the failure of adequate quinine therapy and the absence of parasites from her father, who had been to Italy before the child's birth, but denies having had malaria, and from the child, examined by thick and thin film methods, would seem to exclude malaria.

C. Other infectious agents, such as leishmania : there was no evidence of these.

D. Sickle-celled anaemia : this is unlikely in a white child with no possibility of negro admixture, although it has been reported from America in a Greek (Cooley and Lee, 1929), Italians (Rosenfeld and Pincus, 1932), temporarily in a syphilitic and malarial American of Scotch-Irish ancestry (Sights and Simon, 1931), and in Mexicans (Wallace and Killingsworth, 1935). Against this is the absence of sickling in fresh blood, the absence of the periMalpighian 'pool of blood' described by Rich (1928) as characteristic, and the absence of sickling in the formalin-fixed spleen (Bennett, 1929). The clinical history is not that of typical sickle-celled anaemia, although joint symptoms occurred once (cf. Josephs, 1928).

E. Acholuric jaundice is excluded by the decreased fragility and absence of response to splenectomy.

F. Bone diseases such as myelomatosis, Albers-Schönberg disease, carcinomatosis, myelosclerosis, Hodgkin's disease can be excluded by length of history and absence of radiological evidence.

G. Nutritional anaemia and coeliac disease are excluded by lack of response to liver and by the normal faecal fat.

\section{Discussion}

This disease, of which Whitby and Britton (1937) give most of the important bibliography up to 1937, first described by Cooley and his associates (1925) is now believed by this author and by Whipple and Bradford (1936) to be a congenital and familial disorder of metabolism. All the children previously described, with the three possible exceptions mentioned above, and there are now more than sixty cases reported, have come of Mediterranean stock: Spanish (Sendrail, Lyon and Lasserre, 1936), Italian, Greek, mulatto and Syrian; they have come sometimes from the same village and have been reported in twins and often in families, especially if the parents were related. 
The diagnosis must, therefore, be open to considerable suspicion in a child with a blue-eyed English policeman as father, an English mother and four healthy siblings.

These points favour the diagnosis :

1. The long history of absence of response to treatment (cf. Whipple and Bradford, 1936).

2. The cardiac enlargement and slight left axis deviation (Nemet and Gross, 1936 ; Caffey, 1937).

3. The diameter-thickness ratio. The average cell is abnormally flat ; its volume is on the low side of normal, and the mean haemoglobin content and concentration are both low (as noted by Bradford and Dye, 1936), but the cell thickness is markedly decreased, being $1 \cdot 39 \mu$ as compared with a normal range of $1 \cdot 7-2 \cdot 5 \mu$. The diameter-thickness ratio is thus raised above the upper normal limit of $4 \cdot 2: 1$ and the volume-thickness ratio above the normal $42: 1$. The diameter-thickness ratio is usually normal, it is interesting to note, in pathological conditions, except in acholuric jaundice, when it is decreased, and in some cases of erythroblastic anaemia with idiopathic steatorrhoea, leukoerythroblastic anaemia with myelosclerosis, and cirrhosis of the liver, when it is increased. (Flat cells are not, however, diagnostic of these conditions, as in some other cases a normal ratio was found (Vaughan and Goddard, 1934).) Also, relative flattening occurs in obstructive jaundice, with an increased diameter and increased ratios (diameter/thickness $=5: 1$, volume thickness $=$ $55: 1$ ). This lack of spherocytosis is intimately associated with an increased resistance to hypotonic saline (Haden, 1934) (see below).

4. The resistance to hypotonic saline : this and the large number of target cells in the stained film may possibly in this case be due to splenectomy, since it is said (Whitby and Hynes, 1935) that both the resistance (due to an increase in critical volume, Gordon, Kleinberg and Ponder, 1937) and the target cells are increased after this operation. I have examined, however, through the courtesy of Dr. Whitby, a film of blood from his patient (Moncrieff and Whitby, 1934), and although no splenectomy was performed, there are target cells present, and these authors noted a slightly increased resistance to saline. Many authors note decreased fragility (especially Baty, Blackfan and Diamond, 1932 ; Daland and Worthley, 1935; Frontali, 1937) and some have found a slightly increased fragility as well, although Cooley and Lee (1932), while observing that haemolysis was sometimes incomplete even in distilled water, denied that a prolonged span occurred. It is difficult to correlate the recorded figures, as they have used almost entirely the qualitative and not the quantitative technique. It appears, however, that even in patients that have not been subjected to splenectomy, the span and the resistance are both increased. Since Whitby and Hynes (1935) have shown that the similar increase in resistance in infants is not due, as has been suggested, to the high reticulocyte count, it seems probable that the similar increase here is due not to the immaturity of the red cells, although the nucleated cells behave like leucocytes in such solutions as dilute acetic acid, but to the abnormal shape of the corpuscles eventually formed (see Castle and Daland, 1937). 
5. The Price-Jones curve shows a typical spread, noted in 1934 by Moncrieff and Whitby and in 1936 by Bradford and Dye, with greatly increased standard deviation and coefficient of variation. The latter authors also noted a marked increase in diameter and macrocytosis with a still further increased standard deviation and macrocytosis after splenectomy.

6. The staining defects in the red cells. Since the original observation of these in 1932, although many papers have been published only four mention the defects, three citing Cooley without corroborating him (Kelly and Hill, 1935 ; Yaguda, 1935 ; and Grinnan, 1935), and the other confirming the ' mottled appearance with irregular clumping' (Kato and Downey, 1933). It must be noted that Hitzrot (1928) described an irregular staining of the red cells in this disease. According to Cooley and Lee (1932), a similar but very much less marked irregularity occurs in sickle-celled anaemia, where the cell is smaller and the reticulocytes higher. These defects are present in films from Moncrieff's patient and from other children with typical Cooley's anaemia, which, by the courtesy of Dr. Diamond and Miss Daland of Boston, Massachusetts, I have been enabled to see. They become especially numerous after splenectomy and similar to those in the present case. A few poorly marked defects were seen also in sickle-celled anaemia and in a small proportion after splenectomy for other conditions. They are not present in films from patients with typical acholuric jaundice, leukaemia, pernicious or nutritional anaemia or carcinomatosis with leukoerythroblastic anaemia.

7. The skeletal changes : the picture in general corresponds to a late and sclerotic change (see especially Caffey, 1937). The typical spiculation is not present. This, however, is not a necessity in the diagnosis, as in some cases observed for as long as six years (Caffey) it is never seen (Wollstein and Kriedel, 1930 ; Crawford and Williamson, 1933 ; Hitzrot, 1928) and in other anaemias it is sometimes present : acholuric jaundice (Friedman, 1928 ; Snelling and Brown, 1936), sickle-celled anaemia (Vogt and Diamond, 1930 ; Moore, 1929 ; Le Wald, 1932 ; Rose, 1929 ; Levy and Schnabel, 1932) and erythroblastic anaemia of Gee-Thaysen disease (Bennett, Hunter and Vaughan, 1932) ).

8. The spleen : this presents a variable picture as described in the literature. It is impossible to describe anything as typical, although there is generally fibrosis, sometimes erythroblastic activity, and occasionally reticulo-endothelial proliferation. In this case it is unlike the only other spleen section from a case of Cooley's anaemia that I have seen (Moncrieff and Whitby, 1934), which showed wide pulp spaces, but it corresponds closely with a description by Capper, 1931, Case II.

9. The response to splenectomy, of which the only obvious effect was to increase the nucleated red cells in the blood. This phenomenon occurs constantly in the disease, and the rise is often startling, e.g. from 100 to 7000 per c. mm. (Fries, Duhan and Shair, 1933). In other diseases splenectomy does not produce such an effect (Wollstein and Kriedel, 1930). In this patient there are no definite figures, but 'occasional' become ' numerous' nucleated red cells after splenectomy, until to-day when they number between 50,000 and 100,000 per c. mm. While the opinion has been held that splenectomy may 
retard the progress of the disease (e.g. Cooley,1932), the majority of observers now believe that neither this nor any other treatment except general hygienic measures and the prevention of deficiency anaemia has any effect on its usually prolonged and ultimately fatal course. (See especially Whipple and Bradford, 1936.)

10. The test-meal findings are similar to those of Racugno (1936), who found, with histamine test meals, traces of free acid in two, no traces in two other cases, and Whipple and Bradford (1932), who found with an alcohol meal no free acid in one case.

\section{Conclusions}

This child is suffering from a chronic erythroblastic anaemia indistinguishable from Cooley's anaemia. Whether this label with its prognostic implications should be withheld on 'racial grounds' is a debatable point. It would seem of more practical use to include this case and other cases of atypical ' haemolytic' jaundice showing decreased fragility and defects of the erythrocytes, bone changes and a similar response to splenectomy until other differences are discovered. More observations on the red cell staining defects may clarify the situation.

\section{Summary}

An anaemia similar to the Cooley type in an English child of ten years is recorded, with observations on staining defects, fragility and size of the red cells.

I am indebted to Dr. J. N. O'Reilly, under whose care the child has been, for permission to publish this record and for his advice and helpful criticisms ; to Dr. W. Smith for some of the pathological examinations, and to Dr. Fane Tierney for the skiagrams.

\section{REFERENCES}

Baty, J. M., Blackfan, K. D., and Diamond, L. K. (1932). Amer. J. Dis. Child., 43, 667. Bennett, G. A. (1929). Arch. Path., 7, 801.

Bennett, T. I., Hunter, D., and Vaughan, J. M. (1932). Quart. J. Med., 1, 603.

Bradford, W. L., and Dye, J. (1936). J. Pediat., 9, 312.

Bush, G. B. (1937). Brit. J. Radiol., 10, 491.

Caffey, J. (1937). Amer. J. Roentgen., 37, 293.

Capper, A. (1931). Amer. J. med. Sci., 181, 620.

Castle, W. B., and Daland, G. A. (1937). Amer. J. Physiol., 120, 371.

Cooley, T. B., and Lee, P. (1925). Trans. Am. Ped. Sec., 37, 29.

- (1929). Amer. J. Dis. Child., 38, 103.

(1932). Ibid., 43, 705.

Whitwer, E. R. and Lee, P. (1927). Ibid., 34, 347.

Crawford, R., and Williamson, R (1933). Ibid., 46, 565.

Daland, G. A., and Worthley, K. (1935). J. Lab. clin. Med., 20, 1122.

Friedman, L. J. (1928). Amer. J. Roentgen., 20, 440.

Fries, J. H., Duhan, E., and Shair, H. M. (1933). J. Pediat., 2, 487.

Frontali, G. (1937). Mschr. Kinderheilk, 68, 217.

Gordon, A. S., Kleinberg, W., and Ponder, E. (1937). Amer. J. Physiol, 120, 150. 
Grinnan, A. G. (1935). Amer. J. Roentgen., 34, 297.

Haden, R. L. (1934). Amer. J. med. Sci., 188, 441.

Hitzrot, J. M. (1928). Ann. Surg., 88, 361.

Hunter, F. T. (1936). New Engl. J. Med., 214, 1123.

Hynes, M., and Martin, L. C. (1936). J. Path. Bact., 43, 99.

Josephs, H. (1928). Bull. Johns Hopkins Hosp., 43, 397.

Kato, K., and Downey, H. (1933). Fol. Haem., 50, 55.

Kelly, D. H., and Hill, L. F. (1935). J. Iowa State med. Soc., 25, 9.

Leivy, F. E., and Schnabel, T. G. (1932). Amer. J. med. Sci., 183, 381.

Lewald, L. T. (1932). Radiology, 18, 792.

Moncrieff, A., and Whitby, L. E. H. (1934). Lancet, 2, 648.

Moore, S. (1929). J. Missouri med. Ass., 26, 561.

Nemet, G., and Gross, H. (1936). Amer. Heart J., 12, 352.

Nittis, S., and Spiliopoulos, G. (1937). Amer. J. Dis. Child., 54, 60.

Racugno, A. (1936). Clin. Pediat., 18, 129.

Rich, A. R. (1928). Bull. Johns Hopkins Hosp., 43, 398.

Rose, C. B. (1929). Radiology, 13, 508.

Rosenfeld, S., and Pincus, J. B. (1932). Amer. J. med. Sci., 184, 674.

Sendrail, M., Lyon, A., and Lasserre, J. (1936). Bull. Soc. Med. des Hopitaux de Paris, 52 902.

Sights, W. P., and Simon, S. D. (1931). J. Med., 12, 177.

Snelling, C. E., and Brown, A. (1936). J. Pediat., 8, 330.

Spyropoulos, N. (1836). Rev. Franc. de Ped., 12, 504.

Vaughan, J. M. (1936). The Anaemias, London. and Goddard, H. M. (1934). Lancet, $1,513$.

Vogt, E. C., and Diamond, L. K. (1930). Amer. J. Roentgen., 23, 625.

Wallace, S. A., and Killingsworth, W. P. (1935). Amer. J. Dis. Child., 50, 1208.

Whipple, G. H., and Bradford, W. L. (1932). Ibid., 44, 336. (1936). J. Pediat., 9, 279.

Whitby, L. E. H., and Britton, C. J. C. (1937). Disorders of the Blood, London.

and Hynes, M. (1935). J. Path. Bact., 40, 219.

Wintrobe, M. M. (1933). Amer. J. med. Sci., 185, 58. and Landsberg. J. W. (1935). Ibid., 189, 102.

Wollstein, M., and Kriedel, K. V. (1930). Amer. J. Dis. Child., 39, 115.

Yaguda, A. (1935). Amer. J. Clin. Path., 5, 266. 